\title{
Methicillin-resistant Staphylococcus aureus in air and surfaces of hospital wards: a comparison between new and old buildings
}

\author{
Mohadeseh Choubdar ${ }^{1}$, Shaghayegh Mousavi ${ }^{2}$, Babak Pakbin $^{3}$, Zohreh Naghdali $^{4}$, Babak Rahmani ${ }^{5}$, Ahmad \\ Nikpey $^{6}$
}

${ }^{1}$ M.Sc. in Occupational Health Engineering, Department of Occupational Health, School of Health, Qazvin University of Medical Science, Qazvin, Iran

${ }^{2} \mathrm{Ph}$.D. Student in Molecular Medicine, Faculty of Medical, Qazvin University of Medical Science, Qazvin, Iran

${ }^{3} \mathrm{Ph} . \mathrm{D}$. in Food Hygiene and Quality Control, Faculty of Veterinary Medicine, Department of Food Hygiene and Quality of Control, University of Tehran, Tehran, Iran

${ }^{4}$ Department of Environmental Health Engineering, School of Health, Qazvin University of Medical Sciences, Qazvin, Iran

${ }^{5}$ Ph.D. in Molecular Medicine, Department of Molecular Medicine, Faculty of Medical Sciences, Qazvin University of Medical Sciences, Qazvin, Iran

${ }^{6}$ Ph.D. in Occupational Health Engineering, Associate Professor, Department of Occupational Health, School of Health, Qazvin University of Medical Sciences, Qazvin, Iran

Type of article: Original

\begin{abstract}
Background: Airborne particles that contain Methicillin resistant Staphylococcus aureus (MRSA) can be transferred from hospital air and environmental surfaces. It presents special risks of infections to patients and personnel and imposes exorbitant financial costs and human losses.

Objective: This research has been done to determine the prevalence of MRSA in the air and on surfaces of different hospitals wards.

Methods: In this cross-sectional study, surfaces and air samples were collected from 12 wards of new and oldbuilding hospitals, following identification of MRSA by detection of $p v l$, mecA and vanA genes using Polymerase chain reaction (PCR) assay in 2017. Both hospitals are located in the north of Qazvin city (population: 596,932), Iran, with 255 and 230 patients' beds respectively. Also, some environmental properties of the sampling areas were measured. The data were analyzed using IBM-SPSS version 23, parametric tests and Pearson productmoment correlation.

Results: S. aureus and Gram-negative bacteria were detected in 59.6 and $80 \%$ of the samples. The Intensive care unit (ICU) with $7.5 \%$ MRSA prevalence was the most contaminated ward. S. aureus was detected in $20 \%$ of the surface samples while MRSA was isolated in $16.7 \%$. There are positive correlations between bacterial contamination levels of the air, surfaces and the $\mathrm{CO}_{2}$ concentration of the sampling spaces $(\mathrm{p}<0.0001)$.

Conclusion: According to the findings of this study, air and surfaces of hospitals are contaminated with MRSA. Because of significant correlation between bioaerosol concentration and fomites, to reduce and control prevalence of MRSA, using air cleaning systems as well as decontamination of surfaces is suggested.

Keywords: Hospital, Cross Infection, Methicillin-Resistant Staphylococcus aureus, Air Pollution, Environmental Microbiology
\end{abstract}

\section{Corresponding author:}

Associate Professor Dr. Ahmad Nikpey. Department of Occupational Health, School of Health, Qazvin University of Medical Sciences, Qazvin, Iran. Tel: +98.2833345862, Email: anikpey@qums.ac.ir and nikpey@gmail.com Received: May 05, 2020, Accepted: December 21, 2020, Published: March 2021

iThenticate screening: December 21, 2020, English editing: January 23, 2021, Quality control: February 02, 2021

Ethics approval: Qazvin University of Medical Sciences ethical committee (Ref: IR.QUMS.REC.1396.286)

(C) 2021 The Authors. This is an open access article under the terms of the Creative Commons Attribution-NonCommercialNoDerivs License, which permits use and distribution in any medium, provided the original work is properly cited, the use is non-commercial and no modifications or adaptations are made. 


\section{Abbreviations / Acronyms:}

ARNI: antibiotic-resistant nosocomial infections; GNB: Gram-negative bacteria; ICU: Intensive care unit; I/O: Indoor-to-outdoor concentration ratio; mecA: Methicillin Resistance Gene; MRSA: Methicillin resistant Staphylococcus aureus; PCR: Polymerase chain reaction; vanA: Vancomycin resistance gene.

\section{Introduction}

Nosocomial infections have recently been considered as health threatening and economic loss causes in health care systems and medical microbiology (1). Hospital antibiotic overuse leads to increase in the spread of antimicrobial resistance. In the United States, more than thirty billion dollars annually is dedicated to the treatment of antibioticresistant nosocomial infections (ARNI). Some pathogens causing ARNI including Pseudomonas aeruginosa, Aspergillus species and Staphylococcus aureus are transmitted from air, surfaces, workers and faculties of different hospital wards to patients (2). S. aureus, a non-spore-forming gram-positive cocci, is a microflora of human skin and mucus membrane. This pathogen is one of the most important causes of ARNI transmitted from the hands of workers and faculty to different parts of medical environments, directly to patients (3). According to a report in the U.S., approximately 120,000 S. aureus bloodstream infections and 20,000 associated fatalities occurred in 2017 (2). The principal challenge of this pathogen in hospital infections is antimicrobial resistance properties against methicillin antibiotic family. Methicillin-resistant Staphylococcus aureus (MRSA) is an antibiotic-resistant category of $S$. aureus which is also resistant to other antibiotics such as vancomycin, linezolid, trimethoprim/sulfamethoxazole and ceftobiprole as 5th generation of cephalosporine antibiotic. MRSA has been recently identified in clinical samples by molecular techniques as rapid, specific and sensitive methods (4). Resistance to methicillin is characterized in the genome of MRSA isolates by the (Methicillin Resistance Gene) mecA gene. Vancomycin resistance gene (vanA) also was reported positive in MRSA isolates in several studies previously. $S$. aureus is usually identified in clinical and environmental samples by detection of some specific virulence factor encoding genes. A cytotoxin released by S. aureus, Panton-Valentine Leukocidin ( $p v l$ ) encoded gene is commonly detected by molecular techniques to identify and confirm the positive coagulase $S$. aureus in clinical samples (5). Consequently, rapid detection and identification of MRSA and determination of antimicrobial susceptibility patterns of this pathogen are effective strategies to decrease the prevalence and the risk of lethality in hospitalized patients (6).

Air and surfaces of different wards in the hospital may be subject to transmitted contamination with MRSA the health of the patients may be threatened (7). MRSA has been shown as airborne nosocomial pathogen. Previous studies of air circulation in hospitals and wards revealed that intensive care units and isolation rooms have the transmission potential of carrying MRSA to patients, especially as an airborne pathogen (8). Regarding contaminated surfaces in hospital wards, healthcare workers are the most suspect for transmitting MRSA as confirmed by several researchers (9). However, other surfaces including gowns, gloves, masks, clothes and nursing staff in general have the transmission potential. Nevertheless, MRSA is a principal cause of fatal nosocomial infections; survey and examination of the spreading pattern of this pathogen for air and surfaces of different hospital wards is necessary to be evaluated at regular intervals (10). Iran is faced with significant growth of antibiotic resistance (11). To the best of our knowledge, previous research in Qazvin city, Iran, has tended to focus on MRSA strains that are isolated from patients and personnel and have considered individual factors such as age, gender, type of disease, etc. (12-14), while MRSA transmission factors as contamination of air and fomites in hospitals and some environmental parameters have not been examined. A key drawback with much of the study on MRSA infections is that researchers have described prevalence of this pathogen in clinical isolates, and monitoring of hospital environments as infection prevention and control have not been noted. Therefore, in the present study, we determined the pattern of MRSA prevalence isolated from air and surfaces of different hospital wards using Polymerase chain reaction (PCR) assay with specific primers for detection of virulence factor and antimicrobial susceptibility genes in isolates.

\section{Material and Methods}

\subsection{Subjects}

This descriptive-analytical and cross-sectional study was conducted between March and September 2017. Air and surface samples were collected from different wards of two educational hospitals, one new and one old, with 255 and 230 patients' beds respectively. Both hospitals are located in the north of Qazvin city (population: 596,932), Iran (15). The wards of hospitals subjected to sampling included emergency, Intensive care unit (ICU), surgery, coronary care unit $(\mathrm{CCU})$, operating theatres, orthopedic wards and air samples from landscape spaces of each 
hospital. For determination of indoor-to-outdoor concentration ratio (I/O), one outdoor station was chosen to compare the measurement of data inside the hospital with those outside the hospital.

\subsection{Measurement}

\subsubsection{Sampling and isolation of S. aureus}

Air sampling was conducted based on NIOSH 0800 sampling standard method (16) using a QuickTake 30 sample pump (SKC, Inc. USA) positioned in the center of the rooms, one-meter distance from the wall ledge and the hospital beds. All air samples were taken from an inflow of 28.3 L.min-1 for 10 minutes. Sampling was carried out on two days each week in a time period between 08:00-14:00. All air samples were cultured on Manitol Salt Agar (ProMedia, Spain) and Eosin Methylene Blue Agar (ProMedia, Spain) at $37^{\circ} \mathrm{C}$ for $24 \mathrm{~h}$. For surface sampling, swap sampling was performed on a $10 \times 10 \mathrm{~cm}$ area for different surfaces consisting of covers, clothes, dining tables, serum holders, computers in nurse stations, and on hospital beds. All swap samples were enriched in tryptone soy broth (ProMedia, Spain) overnight at $37^{\circ} \mathrm{C}$ then inoculated on mannitol salt agar (ProMedia, Spain) and eosin methylene blue agar (ProMedia, Spain) and incubated at $37^{\circ} \mathrm{C}$ for $48 \mathrm{~h}$. All presumptive colonies were subjected to coagulase test. All coagulase positive isolates were evaluated for methicillin resistance characteristic using minimum inhibitory concentration (MIC) method (17). Antimicrobial resistance properties of strains were detected and confirmed for oxacillin and cefoxitin antibiotics (Oxoid, UK). Temperature and relative humidity were measured using Indoor Air Quality Meter model IAQ55 (Supco, Co. USA) during sampling.

\subsubsection{DNA extraction and PCR assay}

Confirmed colonies of MRSA isolates were subjected to DNA extraction. The total genome of isolates was extracted using Sinaclon commercial kit (Sinaclon, Co. Iran) for DNA extraction of gram positive bacteria according to the manufacturer's instructions. Quantitative and qualitative of the extracted DNA were measured by NanoDrop spectrophotometer (Thermo Fisher Scientific, USA). Species-specific genes $p v l$, mecA and vanA were detected for identification of MRSA in this study. Specific primers used for detection of these genes have been described in Table 1. PCR mixture consists of $10 \mu \mathrm{L}$ PCR master mix 2X (Ampliqon, Denmark), $1 \mu \mathrm{L}$ of each primer, $3 \mu \mathrm{L}$ of DNA templates and addition of deionized nuclease free water to final volume was carried out in a $25 \mu \mathrm{L}$ reaction volume. Thermal cycling programs for each primer are described in Table 1. For characterization of PCR products, gel electrophoresis was used on $1.4 \%$ agarose gel with $0.01 \% \mathrm{~V} / \mathrm{V}$ safe staining dye (Ampliqon, Denmark) (18).

Table 1. Primer sequences and thermal cycling program used for identification of MRSA

\begin{tabular}{|l|l|l|l|}
\hline Gene & Primer sequence & Thermal cycling program & Product length \\
\hline mecA & $\begin{array}{l}\text { F-GCAAACGTGGCGAAGAAT } \\
\text { R-TGATCTTCACCTTCTAATGTTTGAG }\end{array}$ & $\begin{array}{l}\text { Initial denaturation: } 6 \mathrm{~min} \text { at } 94^{\circ} \mathrm{C} \text {, followed by } 35 \\
\text { cycles: } 30 \mathrm{~s} \text { at } 95^{\circ} \mathrm{C}, 30 \mathrm{~s} \text { at } 56^{\circ} \mathrm{C} \text { and } 35 \mathrm{~s} \text { at } \\
72^{\circ} \mathrm{C} \text {; finally, } 5 \text { min at } 72^{\circ} \mathrm{C} \text { as final extension step }\end{array}$ & $235 \mathrm{bp}$ \\
\hline pvl & $\begin{array}{l}\text { F-CACGATGCGAGCAATCAATC } \\
\text { R-ACAGCCGTGGATAACTTCTAAA }\end{array}$ & $\begin{array}{l}\text { Initial denaturation: } 6 \text { min at } 94^{\circ} \mathrm{C} \text {, followed by } 40 \\
\text { cycles: } 40 \mathrm{~s} \text { at } 95^{\circ} \mathrm{C}, 40 \mathrm{~s} \text { at } 59^{\circ} \mathrm{C} \text { and } 30 \mathrm{~s} \text { at } \\
72^{\circ} \mathrm{C} \text {; finally, } 7 \text { min at } 72^{\circ} \mathrm{C} \text { as final extension step }\end{array}$ & $452 \mathrm{bp}$ \\
\hline vanA & $\begin{array}{l}\text { F-CATGGCAAGTCAGGTGAAGA } \\
\text { R-TTTCACACCGAAGGATGAGC }\end{array}$ & $\begin{array}{l}\text { Initial denaturation: } 6 \text { min at } 94^{\circ} \mathrm{C} \text {, followed by } 30 \\
\text { cycles: } 40 \mathrm{~s} \text { at } 94^{\circ} \mathrm{C}, 61 \mathrm{~s} \text { at } 57^{\circ} \mathrm{C} \text { and } 30 \mathrm{~s} \text { at } \\
72^{\circ} \mathrm{C} \text { finally, } 5 \text { min at } 72^{\circ} \mathrm{C} \text { as final extension step }\end{array}$ & \\
& & $752 \mathrm{bp}$ \\
\hline
\end{tabular}

\subsection{Statistical analysis}

For statistical analysis, analysis of variance ANOVA followed by Duncan's multiple range test for significant difference evaluation $(\mathrm{p}<0.05)$ was used employing SPSS software version 23.0 (Chicago, IL, USA). The relationships between data were examined by using the Pearson product-moment correlation test. Also, all experimental and statistical measurements were implemented in triplicates.

\subsection{Ethical approve}

This research was approved by Qazvin University of Medical Sciences ethical committee and registered by code IR.QUMS.REC.1396.286.

\section{Results}

At the present study, totally, 180 and 322 surface and air samples respectively were collected from 12 internal wards and 2 places located in the landscape space of two hospitals in spring and winter seasons. Gram-negative bacteria 
(GNB), S. aureus and MRSA were detected in 80, 59.6 and $32.5 \%$ of the air samples respectively. Isolation of MRSA was confirmed by specific-primer PCR assay by detection of $p v l$, mecA and vanA genes (Fig. 1A and B). Table 2 provided the prevalence of airborne pathogens and some environmental characteristics of different sampling wards and places. A significant difference $(\mathrm{p}<0.002)$ was observed for pathogen prevalence between different wards of two hospitals. Bacterial contaminations were observed in more than $18 \%$ of the surface samples from which three MRSA strains were isolated (Table 3). Temperature, relative humidity range and carbon dioxide $\left(\mathrm{CO}_{2}\right)$ gas concentration average of different internal wards of the hospitals were $5.6-21.28{ }^{\circ} \mathrm{C}, 17-44 \%$ and 612.4 ppm respectively as described. ICU and emergency wards with 1505 and 1421 ppm had highest $\mathrm{CO}_{2}$ density.
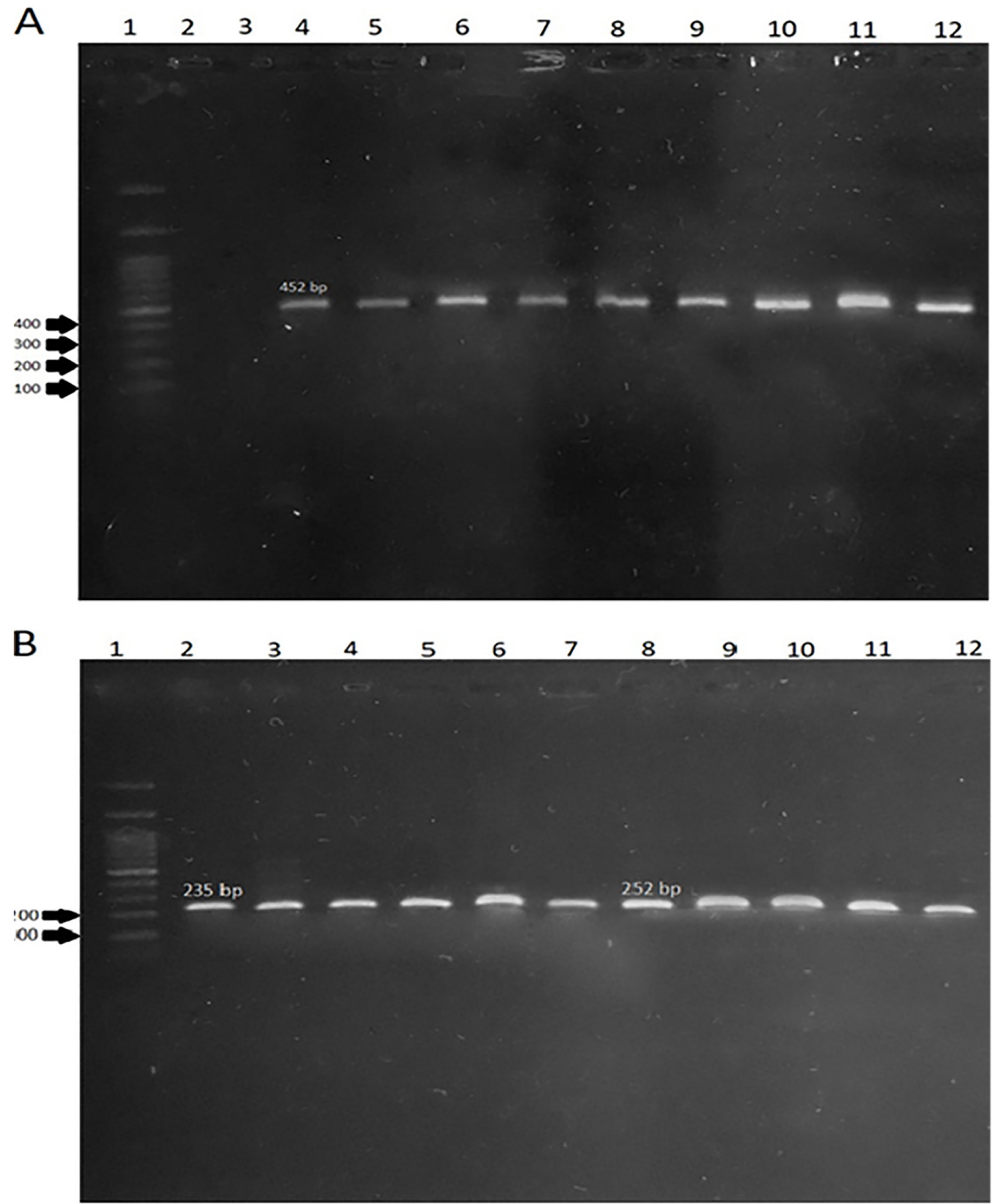

Figure 1 Gel electrophoresis of PCR products for detection of $p v l$ (A; lane 1 as marker, lanes 2 and 3 as negative results and lanes 4-12 as positive results), mecA and vanA (B; lane 1 as marker, lanes 2-7 as positive results for $m e c A$ and lanes 8-12 as positive results for vanA) genes 
Table 2. Bacterial density $\left(\mathrm{CFU} / \mathrm{m}^{3}\right)$, MRSA frequency and environmental characteristics of the wards studied during the two sampling seasons

\begin{tabular}{|c|c|c|c|c|c|c|c|c|}
\hline \multirow[t]{4}{*}{ Hospital } & \multirow[t]{4}{*}{ Ward } & \multirow[t]{4}{*}{ Bioaerosol } & \multicolumn{6}{|l|}{ Season } \\
\hline & & & \multicolumn{3}{|l|}{ Winter } & \multicolumn{3}{|l|}{ Spring } \\
\hline & & & $\begin{array}{l}\text { Bacterial density } \\
\left(\mathrm{CFU} / \mathrm{m}^{3}\right)\end{array}$ & $\mathrm{I} / \mathrm{O}$ & $\begin{array}{l}\text { MRSA } \\
(\%)\end{array}$ & $\begin{array}{l}\text { Bacterial density } \\
\left(\mathrm{CFU} / \mathrm{m}^{3}\right)\end{array}$ & $\mathrm{I} / \mathrm{O}$ & $\begin{array}{l}\text { MRSA } \\
(\%)\end{array}$ \\
\hline & & & Mean \pm SD & & & Mean \pm SD & & \\
\hline \multirow[t]{16}{*}{$\mathrm{A}^{*}$} & \multirow{2}{*}{$\begin{array}{l}\text { Women's } \\
\text { Surgery }\end{array}$} & S. Aureus & $5.6 \pm 4.1$ & 0.9 & 0 & $24.4 \pm 16.9$ & 6.9 & 5 \\
\hline & & GNB & $9.2 \pm 5.3$ & 3.3 & & $11.5 \pm 4.3$ & 1.5 & \\
\hline & \multirow{2}{*}{ Men's Surgery } & S. Aureus & $5.7 \pm 5.9$ & 0.9 & 0 & $10.2 \pm 8.1$ & 2.9 & 0 \\
\hline & & GNB & $10.1 \pm 10.1$ & 3.6 & & $13.5 \pm 18.5$ & 1.8 & \\
\hline & \multirow[t]{2}{*}{ ICU } & S. Aureus & $2.3 \pm 3.9$ & 0.4 & 2.5 & $20 \pm 17$ & 5.7 & 5 \\
\hline & & GNB & $12.2 \pm 12.7$ & 0.4 & & $14.7 \pm 21$ & 1.9 & \\
\hline & \multirow{2}{*}{$\begin{array}{l}\text { Women's } \\
\text { Orthopedic }\end{array}$} & S. Aureus & $17.7 \pm 0$ & 2.8 & 0 & $3.5 \pm 5$ & 1 & 0 \\
\hline & & GNB & $10.6 \pm 5$ & 3.8 & & 7.07 & 0.9 & \\
\hline & \multirow{2}{*}{$\begin{array}{l}\text { Men's } \\
\text { Orthopedic }\end{array}$} & S. Aureus & $15.9 \pm 2.5$ & 2.5 & 2.5 & $7.06 \pm 10$ & 2 & 0 \\
\hline & & GNB & $14.1 \pm 4.9$ & 5 & & $8.8 \pm 7.5$ & 1.2 & \\
\hline & \multirow[t]{2}{*}{ Emergency } & S. Aureus & $17.7 \pm 0$ & 2.8 & 2.5 & 3.5 & 1 & 0 \\
\hline & & GNB & $30 \pm 7.5$ & 10.7 & & 17.7 & 2.3 & \\
\hline & \multirow[t]{2}{*}{ Mean } & S. Aureus & $6.8 \pm 6.5$ & 1.1 & 1.2 & $16.4 \pm 15$ & 4.6 & 1.7 \\
\hline & & GNB & $10.7 \pm 9.8$ & 3.8 & & $11.5 \pm 12.3$ & 1.5 & \\
\hline & \multirow[t]{2}{*}{ Outdoor } & S. Aureus & $6.4 \pm 12.3$ & - & 2.5 & $3.5 \pm 1.4$ & - & 2.5 \\
\hline & & GNB & $2.8 \pm 2.9$ & - & & $7.6 \pm 11.9$ & - & \\
\hline \multirow[t]{16}{*}{$\mathrm{B}^{* *}$} & \multirow{2}{*}{$\begin{array}{l}\text { Women's } \\
\text { Surgery }\end{array}$} & S. Aureus & $1.5 \pm 2.8$ & 0.05 & 0.05 & $6.2 \pm 5.9$ & 0.3 & 2.5 \\
\hline & & GNB & $10.6 \pm 10$ & 0.4 & & $6.6 \pm 6.9$ & 1.1 & \\
\hline & \multirow[t]{2}{*}{ Men's Surgery } & S. Aureus & $4.7 \pm 7.3$ & 0.2 & 0.2 & $4.7 \pm 2.9$ & 0.2 & 2.5 \\
\hline & & GNB & $7.1 \pm 4.5$ & 0.3 & & $7.8 \pm 10.1$ & 1.3 & \\
\hline & \multirow[t]{2}{*}{ ICU } & S. Aureus & $5.3 \pm 7.3$ & 0.2 & 0.2 & $7.4 \pm 6.3$ & 0.3 & 2.5 \\
\hline & & GNB & $11.2 \pm 13.5$ & 0.4 & & $6.1 \pm 8.9$ & 1 & \\
\hline & \multirow{2}{*}{$\begin{array}{l}\text { Operating } \\
\text { room }\end{array}$} & S. Aureus & 0 & 0 & 0 & $9.7 \pm 11.3$ & 0.4 & 0 \\
\hline & & GNB & $1.8 \pm 2.5$ & 0.07 & & $2.6 \pm 5.3$ & 0.4 & \\
\hline & \multirow[t]{2}{*}{$\mathrm{CCU}$} & S. Aureus & $5.3 \pm 2.5$ & 0.2 & 0.2 & $10.6 \pm 5$ & 0.5 & 0 \\
\hline & & GNB & $3.5 \pm 0$ & 0.1 & & $3.5 \pm 0$ & 0.6 & \\
\hline & \multirow[t]{2}{*}{ Emergency } & S. Aureus & $5.3 \pm 7.4$ & 0.2 & 0.2 & $7.07 \pm 0$ & 0.3 & 0 \\
\hline & & GNB & $1.7 \pm 2.5$ & 0.07 & & $3.5 \pm 3.5$ & 0.6 & \\
\hline & \multirow[t]{2}{*}{ Mean } & S. Aureus & $7.4 \pm 14$ & 0.2 & 0.2 & $9.5 \pm 20.2$ & 0.4 & 0.4 \\
\hline & & GNB & $10.7 \pm 12.4$ & 0.4 & 0 & $5.7 \pm 7.1$ & 0.9 & \\
\hline & \multirow[t]{2}{*}{ Outdoor } & S. Aureus & $29.1 \pm 28.3$ & - & - & $23 \pm 51.1 .1$ & - & 0 \\
\hline & & GNB & $24.7 \pm 21.2$ & - & & $5.9 \pm 5.8$ & - & - \\
\hline
\end{tabular}

There is a significant correlation between the environmental characteristics and the prevalence of the MRSA and GNB for collected air samples; however, no significant relationship was found between the number of staff and workers and the prevalence of airborne pathogens (Table 4). I/O ratio commonly was observed as was found for the old hospital observed in the present study where the air is circulated by windows; however, more declination in I/O ratio was observed in the spring season for this hospital. The prevalence of GNB was 9.4 CFU. $\mathrm{m}^{-3}$. The number of workers in each ward, I/O ratio and environmental properties are the main factors for bacterial contamination of the hospital air. GNB was observed in about $15 \%$ of the surface samples, principally detected from the surface of the ICU bed covers. 
http://www.ephysician.ir

Table 3. Distribution of positive surface samples by internal wards of each hospital

\begin{tabular}{|c|c|c|c|c|c|}
\hline Hospital & Ward & Surface & $\begin{array}{l}\text { S. Aureus Dencit } \\
\left(\mathrm{CFU} / \mathrm{cm}^{2}\right)\end{array}$ & $\begin{array}{l}\text { Dencity GNB } \\
\left(\mathrm{CFU} / \mathrm{cm}^{2}\right)\end{array}$ & MRSA (\%) \\
\hline \multirow[t]{17}{*}{ Old } & \multirow{3}{*}{$\begin{array}{l}\text { Women's } \\
\text { Surgery }\end{array}$} & Food Table 2 & 0.02 & 0 & 0 \\
\hline & & Bed Handle 2 & 0.08 & 0.02 & 0 \\
\hline & & Central Hall Rail & 0.06 & 0 & 0 \\
\hline & \multirow{5}{*}{ Men's Surgery } & Nurse Station Desk & 0.02 & 0.06 & 0 \\
\hline & & Bed sheet 2 & 0 & 0.08 & 0 \\
\hline & & Bed Handle 2 & 0.06 & 0 & 1 \\
\hline & & Food Table 12 & 0.04 & 0.46 & 0 \\
\hline & & Serum Leg 12 & 0.02 & 0 & 0 \\
\hline & \multirow[t]{4}{*}{ ICU } & Nurse Station Desk 1 & 0.02 & 0 & 1 \\
\hline & & Keyboard 5 & 0 & 0.04 & 0 \\
\hline & & Food Table 8 & 0.02 & 0 & 0 \\
\hline & & Bed Handle & 0.02 & 0.36 & 0 \\
\hline & \multirow[t]{2}{*}{ Emergency } & Bed sheet 3 & 0.02 & 0 & 0 \\
\hline & & Food Table 8 & 0 & 0.02 & 0 \\
\hline & \multirow{2}{*}{$\begin{array}{l}\text { Men's } \\
\text { Orthopedic }\end{array}$} & Bed Handle 1 & 0.04 & 0 & 0 \\
\hline & & Trolley & 0.02 & 0 & 0 \\
\hline & $\begin{array}{l}\text { Women's } \\
\text { Orthopedic }\end{array}$ & Trolley & 0 & 0.02 & 0 \\
\hline \multirow[t]{9}{*}{ New } & \multirow{2}{*}{$\begin{array}{l}\text { Women's } \\
\text { Surgery }\end{array}$} & Bed sheet 1 & 0.14 & 0.3 & 0 \\
\hline & & Keyboard & 0 & 0.52 & 0 \\
\hline & \multirow[t]{3}{*}{ Men's Surgery } & Keyboard 1 & 0 & 0.02 & 0 \\
\hline & & Bed sheet 8 & 0.02 & 0 & 0 \\
\hline & & Bed sheet 18 & 0 & 0.24 & 0 \\
\hline & \multirow[t]{2}{*}{ ICU } & Bed Handle 11 & 0 & 0.04 & 0 \\
\hline & & Bed sheet 4 & 0.2 & 0 & 1 \\
\hline & \multirow[t]{2}{*}{ Emergency } & Food Table 2 & 0.02 & 0 & 0 \\
\hline & & Trolley & 0.02 & 0 & 0 \\
\hline
\end{tabular}

Table 4. Relationships ${ }^{a}$ between variables according to Pearson product-moment correlation test ${ }^{b}$

\begin{tabular}{|c|c|c|c|c|c|c|c|c|c|c|c|c|c|c|c|}
\hline \multirow{2}{*}{$\begin{array}{l}\text { Sampling } \\
\text { Type }\end{array}$} & \multirow[t]{2}{*}{ Variable } & \multicolumn{3}{|c|}{ Air Samples } & \multicolumn{3}{|c|}{ Surface Samples } & \multirow[t]{2}{*}{ Temperature } & \multirow{2}{*}{$\begin{array}{l}\text { Relative } \\
\text { Humidity }\end{array}$} & \multirow{2}{*}{$\begin{array}{l}\mathrm{CO}_{2} \\
\text { Concentration }\end{array}$} & \multirow[t]{2}{*}{$n^{c}$} & \multirow{2}{*}{\begin{tabular}{|l} 
Bed \\
sheets \\
change
\end{tabular}} & \multirow[t]{2}{*}{ Cleaning } & \multirow[t]{2}{*}{ Season } & \multirow[t]{2}{*}{ Temperature } \\
\hline & & \begin{tabular}{|l|}
$S$. \\
Aureus
\end{tabular} & GNB & MRSA & \begin{tabular}{|l|}
$S$. \\
Aureus
\end{tabular} & GNB & MRSA & & & & & & & & \\
\hline \multirow[t]{3}{*}{$\begin{array}{l}\text { Air } \\
\text { Samples }\end{array}$} & \begin{tabular}{|l}
. \\
Aureus
\end{tabular} & - & $<0.0001$ & $<0.0001$ & $<0.0001$ & $<0.0001$ & 0.02 & 0.47 & 0.23 & $<0.0001$ & 0.86 & 0.26 & 0.38 & 0.06 & - \\
\hline & MRSA & $<0.0001$ & 0.002 & - & 0.01 & 0.002 & 0.09 & 0.37 & 0.24 & 0.02 & 0.7 & 0.33 & 0.79 & 0.08 & $<0.0001$ \\
\hline & GNB & $<0.0001$ & - & 0.002 & 0.24 & - & 0.11 & 0.80 & 0.03 & $<0.0001$ & 0.62 & 0.64 & 0.13 & 0.16 & $<0.0001$ \\
\hline \multirow[t]{3}{*}{$\begin{array}{l}\text { Surface } \\
\text { Samples }\end{array}$} & \begin{tabular}{|l|} 
S. \\
Aureus
\end{tabular} & 0.62 & $<0.0001$ & 0.98 & 0.10 & - & $<0.0001$ & 0.46 & 0.81 & 0.88 & 0.49 & - & 0.49 & 0.48 & 0.62 \\
\hline & MRSA & $<0.0001$ & 0.24 & 0.01 & - & 0.10 & 0.47 & 0.25 & 0.36 & 0.11 & 0.87 & - & 0.33 & 0.16 & $<0.0001$ \\
\hline & GNB & 0.65 & 0.11 & 0.07 & 0.47 & $<0.0001$ & - & 0.46 & 0.81 & 0.88 & 0.02 & - & - & 0.49 & 0.65 \\
\hline
\end{tabular}

${ }^{\text {a }}$ Statistical significant was set at $\mathrm{p}<0.05,{ }^{\mathrm{b}}$ Numbers are presented in $\mathrm{p}$-values, ${ }^{\mathrm{c}}$ Number of persons

\section{Discussion}

In this study, total air contamination rate of two hospitals were observed at about $60 \%$ which was higher than that reported by Azarian et al. (2015) in India (19). S. aureus was detected in $20 \%$ of the surface samples while MRSA was isolated in $16.7 \%$. There are many research that isolated varied prevalence levels of MRSA from air and surfaces of the different hospital wards (20). Mukhyia et al. observed 14.3\% prevalence of $S$. aureus as an airborne pathogen in hospital samples while MRSA was isolated in 40.7\% of samples which is higher than that detected in our study (32.5\%) (21). Creamer et al. and Mirzaii et al. isolated MRSA in 14.4 and $66.7 \%$ of the samples collected from different wards of the hospitals respectively $(10,22)$. We detected the most prevalence of MRSA in the ICU ward. Wagenvoort et al. isolated MRSA from air samples from the ICU ward even eight weeks after the patients had been discharged (23). As previously described by researchers; higher prevalence of MRSA are in the ICU and CCU wards of the hospitals as the principal causes of the nosocomial infections in these places (24). Due to the fact that 
antibiotic treatment with different consumption levels is carried out in the hospital wards (25) a significant difference of MRSA average emerged. Because of long hospitalization period and strong antibiotic treatment, patients in the ICU have more potential to be subjected to MRSA (26). Therefore, microbial environment quality will need to be more considered in intensive care units.

The frequency of GNB in surfaces was $15 \%$ which is consistent with previous results (27). The ability of adaptation to environmental conditions in GNB is the reason for survival of these bacteria in surfaces (28). Several outbreaks have demonstrated that surface contamination by GNB and MRSA plays a role in continued transmission in hospitals (29-31). As shown in Table 3, areas around patients such as bed sheets and bed handles were contaminated with MRSA that are touched frequently by workers and patients. Significant correlation was found between MRSA contamination in surfaces and number of persons $(\mathrm{p}=0.02)$. This can be attributed to the traffic of people in a hospital environment that can lead to an increase in the number of surfaces touched by hands. Thus, improved efficiency of disinfection and routine environmental sampling can be taken to prevent or reduce the incidence of contamination of surfaces and hospital acquired infections.

The concentration of isolated S. aureus was between 2.24-3.40 CFU.m ${ }^{-3}$ higher than that observed by Ho et al. (32) and lower than Nandalal and Somashekar's report (33). We detected higher levels of airborne pathogens in the old hospital. The most contaminated place with $S$. aureus was the ICU ward in the old hospital with 15.9 CFU.m ${ }^{-3}$ bacterial load. The most important causes of difference in $S$. aureus contamination levels between old and new hospitals were air purification systems. There had been no suitable ventilation or air purification system in the old hospital for more than forty years; In light of the reported indoor/outdoor ratio $\mathrm{I} / \mathrm{O}>1$, it could be reasonably described as entering ambient air inside the old hospital building. Hence the doors and windows need to be kept closed or the use of purified outdoor air by filtration is needed, to minimize airborne spread of MRSA. The new hospital is equipped with a modern central air circulation and purification system that dilutes airborne microbial concentration and removes microbes via an outside air exhaust. There was a strong correlation between $\mathrm{CO}_{2}$ concentration, bacterial bioaerosols and the seasons, which is similar to the study of Hwang et al. (34). Peak of $\mathrm{CO}_{2}$ density was observed in ICU and emergency wards, which is in result of inadequate air movement and overcrowding in limited spaces. Then higher $\mathrm{CO}_{2}$ concentration of the hospitals' air indicates lower efficiency of the air ventilation and more airborne bacterial load. In addition, an increase of $\mathrm{CO}_{2}$ concentration up to $1000 \mathrm{ppm}$ leads to some diagnostic medical errors (35). Many studies have suggested the use of ventilation and purification systems to reduce infectious agents in hospitals $(36,37)$. Some classic strategies including washing hands, and hygienic and sterilization procedures could be effective in reducing airborne pathogens (38). As $S$. aureus is carried by one third of the human population (25), an effective monitoring program should be established to detect, identify and control this pathogen transmitted from the staff and patients to the air and surfaces of the sensitive hospital wards.

Our results have been in agreement with other researchers regarding the correlation between air and surface contamination of MRSA in hospitals $(10,22,39)$. This correlation can be due to activities by colonized or infected patients; aerosols are produced and disseminated during talking, coughing and sneezing and creating infectious droplet nuclei. Droplets may remain suspended and spread for some time or settle on surfaces and equipment and can be picked up by the hands of health care workers or patients, which is considered as subsequent transmission. As a matter of fact, microbial air quality is significantly related to contamination of the environment and surfaces. Considerable attention must be paid to air cleaning systems as well as decontamination of surfaces and a more rigorous and scientific strategy to assessing healthcare facilities is needed.

\section{Study strength and Limitations}

This paper has highlighted the importance of the link between air and surface contamination of MRSA in hospitals. However, this study was carried out in one city in Iran and due to the limited sample size, the findings cannot be generalized to other hospitals in Iran, which should be targeted in future works. It should be noted that in spite of the existence of a ventilation and filtration system in the new hospital, I/O ratio was below 1 . This indicates contamination accumulation inside the building is due to low performance of ventilation dilution. Thus assessment of ventilation effectiveness, for controlling air quality in hospitals is necessary. One of the limitations of this study is the lack of measurement of ventilation air system parameters. Prospective investigations should examine efficiency factors of ventilation systems, such as air exchange rate, filtration and disinfection systems, airflow, and pressure. 


\section{Conclusions}

The present study has shown prevalence of MRSA in air and surface samples collected from different wards of new and old building hospitals in Qazvin city, Iran. Environmental contamination can be proposed as a source for subsequent transmission of pathogens. Correlation between MRSA contamination in air and surfaces and also $\mathrm{CO}_{2}$ concentration implies insufficient ventilation systems in both hospitals. In conclusion, the control of airborne MRSA in hospitals depends not only on air disinfection but also on surface decontamination. On a wider level, research is also needed to assess the relationship between environmental MRSA and isolates from patients and staff to investigate the role played by environmental contamination in the risk of transmission of this pathogen in healthcare facilities.

\section{Acknowledgments:}

This study was supported by the Qazvin University of Medical Science, grant number: 14002561. We would like to thank the wards managers and staff nurses of the hospitals for their support, without whose help, this work would never have been possible.

\section{Conflict of Interest:}

There is no conflict of interest to be declared.

\section{Authors' contributions:}

Conception or design of the work (MC, SM, BR, AN); Acquisition of data (MC, ZN, AN); Analysis or interpretation of data (MC, BP, AN); Drafting the manuscript (MC, SM, BP, ZN); Revising the manuscript (MC, SM, BP, BR, $\mathrm{AN}$ ); Accountable for all aspects of the work (All author). All authors read and approved the final manuscript.

\section{References:}

1) Khan HA, Baig FK, Mehboob R. Nosocomial infections: Epidemiology, prevention, control and surveillance. Asian Pac J Trop Biomed. 2017;7(5):478-82. DOI: 10.1016/j.apjtb.2017.01.019

2) Kourtis AP, Hatfield K, Baggs J, Mu Y, See I, Epson E, et al. Vital Signs: Epidemiology and Recent Trends in Methicillin-Resistant and in Methicillin-Susceptible Staphylococcus aureus Bloodstream Infections-United States. MMWR Morb Mortal Wkly Rep. 2019;68(9):214-22. DOI: 10.15585/mmwr.mm6809e1. PMid: 30845118, PMCid: PMC6421967

3) Tong SY, Davis JS, Eichenberger E, Holland TL, Fowler VG. Staphylococcus aureus infections: epidemiology, pathophysiology, clinical manifestations, and management. Clin Microbiol Rev. 2015;28(3):603-61. DOI: 10.1128/CMR.00134-14. PMid: 26016486, PMCid: PMC4451395

4) Lee AS, de Lencastre H, Garau J, Kluytmans J, Malhotra-Kumar S, Peschel A, et al. Methicillin-resistant Staphylococcus aureus. Nat Rev Dis Primers. 2018;4:18033. DOI: 10.1038/nrdp.2018.33. PMid: 29849094

5) Lakhundi S, Zhang K. Methicillin-resistant Staphylococcus aureus: molecular characterization, evolution, and epidemiology. Clin Microbiol Rev. 2018;31(4):e00020-18. DOI: 10.1128/CMR.00020-18. PMid: 30209034, PMCid: PMC6148192

6) Yaren H, Saygin O, Turaclar N, Vural H, Turhan A, Tuncer E, et al. Investigation of PVL and MecA Gene Locies in Methicillin-Resistant Staphylococcus aureus (MRSA) Strains Isolated from Nosocomial Samples of Hospital Patients and Hospital Staff. Genomics and Appl Biol. 2015;6(10):1-6. DOI: 10.5376/gab.2015.06.0010

7) Lei H, Jones RM, Li Y. Exploring surface cleaning strategies in hospital to prevent contact transmission of methicillin-resistant Staphylococcus aureus. BMC Infect Dis. 2017;17(1):85-90. DOI: 10.1186/s12879016-2120-z. PMid: 28100179, PMCid: PMC5242018

8) Yuen J, Chung T, Loke A. Methicillin-resistant Staphylococcus aureus (MRSA) contamination in bedside surfaces of a hospital ward and the potential effectiveness of enhanced disinfection with an antimicrobial polymer surfactant. Int J Environ Res Public Health. 2015;12(3):3026-41. DOI: 10.3390/ijerph120303026. PMid: 25768241, PMCid: PMC4377950

9) Loftus RW, Dexter F, Robinson AD. Methicillin-resistant Staphylococcus aureus has greater risk of transmission in the operating room than methicillin-sensitive $\mathrm{S}$ aureus. Am $\mathrm{J}$ Infect Control. 2018;46(5):520-5. DOI: 10.1016/j.ajic.2017.11.002

10) Mirzaii M, Emaneini M, Jabalameli F, Halimi S, Taherikalani M. Molecular investigation of Staphylococcus aureus isolated from the patients, personnel, air and environment of an ICU in a hospital in Tehran. J Infect Public. 2015;8(2):202-6. DOI: 10.1016/j.jiph.2014.09.002. PMid: 25458916 
11) Leylabadlo HE, Pourlak T, Aghazadeh M, Asgharzadeh M, Kafil HS. Extended-spectrum beta-lactamase producing gram negative bacteria In Iran: A review. Afr J Infect Dis. 2017;11(2):39-53. DOI: 10.21010/ajid.v11i2.6. PMid: 28670639, PMCid: PMC5476812

12) Taromian M, Peymani A, Aslanimehr M. Frequency of Fibronectin Binding Protein A and PantonValentine Leukocidin in Methicillin-Resistant Staphylococcus aureus Collected From Educational Hospitals in Qazvin, Iran. Biotech Health Sci. 2016;3(1): e35939. DOI: 10.17795/bhs-35939

13) Nazemsadati SS, Allami A, Haj Manoochehri F. Staphylococcus aureus colonization in Qazvin university hospitals healthcare workers. J Qazvin Univ Med Sci. 2018;22(2):8-19.

14) Azimi A, Moosavi ME, Peymani A. Phenotypic and Genotypic Characterization of Methicillin and Erythromycin Resistance in Staphylococcus aureus Collected from Nasal Samples in Qazvin Medical Students. Iranian Journal of Infectious Diseases And Tropical Medicine. 2019;23(83):55-65.

15) Alimanesh N, Taheri M, Sadeghi A. Selection from the results of the general population and housing census of the year 2016. Qazvin: Management and Planning Organization of Qazvin province; 2017 Aug. $19 \mathrm{p}$.

16) Health, Prevention, Dept HS. Niosh Criteria for a Recommended Standard: Occupational Exposure to Heat and Hot Environments: National Institute on Drug Abuse; 2018.

17) Holmes NE, Turnidge JD, Munckhof WJ, Robinson JO, Korman TM, O'Sullivan MV, et al. Antibiotic choice may not explain poorer outcomes in patients with Staphylococcus aureus bacteremia and high vancomycin minimum inhibitory concentrations. J Infect Dis. 2011;204(3):340-7. DOI: 10.1093/infdis/jir270, PMid: 21742831

18) Ghahremani M, Jazani NH, Sharifi Y. Emergence of vancomycin-intermediate and-resistant Staphylococcus aureus among methicillin-resistant S. aureus isolated from clinical specimens in the northwest of Iran. J Glob Antimicrob Resist. 2018;14:4-9. DOI: 10.1016/j.jgar.2018.01.017. PMid: 29454049

19) Azarian T, Cook RL, Johnson JA, Guzman N, McCarter YS, Gomez N, et al. Whole-genome sequencing for outbreak investigations of methicillin-resistant Staphylococcus aureus in the neonatal intensive care unit: time for routine practice? Infect Control Hosp Epidemiol. 2015;36(7):777-85. DOI: 10.1017/ice.2015.73. PMid: 25998499, PMCid: PMC4507300

20) de la Gandara MP, Curry M, Berger J, Burstein D, Della-Latta P, Kopetz V, et al. MRSA causing infections in hospitals in greater metropolitan New York: major shift in the dominant clonal type between 1996 and 2014. PloS one. 2016;11(6):e0156924. DOI: 10.1371/journal.pone.0156924. PMid: 27272665, PMCid: PMC4896443

21) Mukhiya R, Shrestha A, Rai S, Pant K, Rai G, Singh R. Methicillin-resistant Staphylococcus aureus in clinical samples of hospital located in kathmandu valley, Nepal. Res J Pharm Biolo Chem Sci. 2013;4(2):617-21.

22) Creamer E, Shore AC, Deasy EC, Galvin S, Dolan A, Walley N, et al. Air and surface contamination patterns of meticillin-resistant Staphylococcus aureus on eight acute hospital wards. J Hosp Infect. 2014;86(3):201-8. DOI: 10.1016/j.jhin.2013.12.005. PMid: 24529449

23) Wagenvoort J, Toenbreker H, Nurmohamed A, Davies B. Transmission of methicillinresistantStaphylococcus aureus within a household. Eur J Clin Microbiol Infect Dis. 1997;16(5):399-400. DOI: 10.1007/BF01726373. PMid: 9228485

24) Lax S, Gilbert JA. Hospital-associated microbiota and implications for nosocomial infections. Trends Mol Med. 2015;21(7):427-32. PMID: 25907678 DOI: 10.1016/j.molmed.2015.03.005

25) Mirhoseini SH, Nikaeen M, Shamsizadeh Z, Khanahmad H. Hospital air: A potential route for transmission of infections caused by $\beta$-lactam-resistant bacteria. Am J Infect Control. 2016;44(8):898-904. DOI: 10.1016/j.ajic.2016.01.041. PMid: 27021512

26) van de Sande-Bruinsma N, van Hall MAL, Janssen M, Nagtzaam N, Leenders S, de Greeff SC, et al. Impact of livestock-associated MRSA in a hospital setting. Antimicrob Resist Infect Control. 2015;4(1):11. DOI: 10.1186/s13756-015-0053-8. PMID: 25908965, PMCid: PMC4407377

27) Getchell-White SI, Donowitz LG, Groschel DH. The inanimate environment of an intensive care unit as a potential source of nosocomial bacteria evidence for long survival of Acinetobacter calcoaceticus. Infect Control Hosp Epidemiol. 1989;10(9):402-7. DOI: 10.1086/646061. PMid: 2794465

28) Falagas ME, Skalidis T, Vardakas KZ, Legakis NJ. Activity of cefiderocol (S-649266) against carbapenemresistant Gram-negative bacteria collected from inpatients in Greek hospitals. J Antimicrob Chemother. 2017;72(6):1704-8. DOI: 10.1093/jac/dkx049. PMid: 28369471 
29) Denton M, Wilcox M, Parnell P, Green D, Keer V, Hawkey P, et al. Role of environmental cleaning in controlling an outbreak of Acinetobacter baumannii on a neurosurgical intensive care unit. J Hosp Infect. 2004;56(2):106-10. DOI: 10.1016/j.jhin.2003.10.017. PMid: 15019221

30) Zanetti G, Blanc DS, Federli I, Raffoul W, Petignat C, Maravic P, et al. Importation of Acinetobacter baumannii into a burn unit: a recurrent outbreak of infection associated with widespread environmental contamination. Infect Control Hosp Epidemiol. 2007;28(6):723-5. DOI: 10.1086/517956. PMid: 17520548

31) Hardy KJ, Oppenheim BA, Gossain S, Gao F, Hawkey PM. A study of the relationship between environmental contamination with methicillin-resistant Staphylococcus aureus (MRSA) and patients' acquisition of MRSA. Infect Control Hosp Epidemiol. 2006;27(2):127-32. DOI: 10.1086/500622. PMid: 16465628

32) Ho C-M, Li C-Y, Ho M-W, Lin C-Y, Liu S-H, Lu J-J. High rate of qacA-and qacB-positive methicillinresistant Staphylococcus aureus isolates from chlorhexidine-impregnated catheter-related bloodstream infections. Antimicrob Agents Chemother. 2012;56(11):5693-7. DOI: 10.1128/AAC.00761-12. PMid: 22908163, PMCid: PMC3486537

33) Nandalal P, Somashekar R. Prevalence of Staphylococcus aureus and Pseudomonas aeruginosa in indoor air flora of a district hospital, Mandya, Karnataka. J Environ Biol. 2007;28(2):197-200. PMid: 17915750

34) Hwang SH, Roh J, Park WM. Evaluation of PM10, CO2, airborne bacteria, TVOCs, and formaldehyde in facilities for susceptible populations in South Korea. Environ Pollut. 2018;242:700-8. doi: 10.1016/j.envpol.2018.07.013. PMid: 30029169.

35) Chaivisit P, Fontana A, Galindo S, Strub C, Choosong T, Kantachote D, et al. Airborne Bacteria and Fungi Distribution Characteristics in Natural Ventilation System of a University Hospital in Thailand. EnvironmentAsia. 2018;11(2):53-66. DOI: 10.14456/ea.2018.22

36) Barbut F, Yezli S, Mimoun M, Pham J, Chaouat M, Otter JA. Reducing the spread of Acinetobacter baumannii and methicillin-resistant Staphylococcus aureus on a burns unit through the intervention of an infection control bundle. Burns.2013;39(3):395-403. DOI: 10.1016/j.burns.2012.07.007. PMid: 22884127

37) Aliabadi AA, Rogak SN, Bartlett KH, Green SI. Preventing airborne disease transmission: review of methods for ventilation design in health care facilities. Adv Prev Med. 2011;2011:1-21. DOI: 10.4061/2011/124064. PMid: 22162813. PMCid: PMC3226423

38) Stawicki SP, Brisendine C, Levicoff L, Ford F, Snyder B, Eid S, et al. Comprehensive and Live Air Purification as a Key Environmental, Clinical, and Patient Safety Factor: A Prospective Evaluation. In: Stawicki SP, MS Firstenberg, editors. Vignettes in Patient Safety. 2019. vol. 4. P.138-153. DOI: 10.5772/intechopen.84530

39) Sexton T, Clarke P, O'neill E, Dillane T, Humphreys H. Environmental reservoirs of methicillin-resistant Staphylococcus aureus in isolation rooms: correlation with patient isolates and implications for hospital hygiene. J Hosp Infect. 2006;62(2):187-94. DOI: 10.1016/j.jhin.2005.07.017. PMid: 16290319. 